\title{
Az Európai Újraélesztési Tanács (European Resuscitation Council, ERC) 2021-es irányelveinek áttekintése - Elsősegélynyújtás
}

\author{
Bánfai-Csonka Henrietta ${ }^{1,2,3}$, Prof. Dr. Betlehem József ${ }^{1}$, \\ Musch János $^{1}$, Dr. Bánfai Bálint ${ }^{1}$ \\ ${ }^{1}$ Pécsi Tudományegyetem Egészségtudományi Kar Sürgősségi Ellátási és Egészségpedagógiai Intézet, \\ Egészségpedagógiai és Alapozó Sürgősségi Tanszék, Pécs \\ 2 Pécsi Tudományegyetem Egészségtudományi Kar Egészségtudományi Doktori Iskola, Pécs \\ ${ }^{3}$ Pécsi Tudományegyetem Klinikai Központ Sürgősségi Betegellátó Osztály
}

\section{Levelező szerző: Dr. Bánfai Bálint}

Az Európai Újraélesztési Tanács (European Resuscitation Council, ERC) hivatalos irányelvei nagy általánosságban - érthető módon - a keringésmegállás és ennek ellátását helyezik a fó fókuszba. Ennek ellenére számos más kórfolyamat is előfordul, melyek azonnali beavatkozást igényelnek, hiszen enélkül - sőt sajnos bizonyos esetekben ezzel együtt is - súlyos, életet közvetlenül veszélyeztető helyzetek alakulnak ki. Ezen kórfolyamatok ellátása az elsősegélynyújtás tárgykörébe tartozik. Az ERC 2015-ben kiadott hivatalos ajánlásában foglalkozott elöször külön fejezetben az elsősegélynyújtással [1]. Az ERC 2021-ben megjelent új ajánlásában ez újra megfigyelhető, az elsősegélynyújtás ismét külön fejezetet kapott. A következőkben tételesen szeretnénk bemutatni azokat a helyzeteket és ezek javasolt ellátási módjait, melyek a jelenlegi ERC ajánlásban tárgyalásra kerülnek [2].

Az itt összefoglalt ajánlás vázlata a jelenleg elérhető tudományos bizonyítékok alapján [3], az „Elsősegélynyújtás munkabizottság” által került megfogalmazásra, majd a nyilvánossá tételt követő megjegyzések mérlegelése és beépítése után került véglegesítésére.

Az ajánlásban tárgyalt témakörök két fő kategóriába kerültek besorolásra: nem traumás eredetű, sürgősségi ellátást igénylő kórképek, illetve traumás eredetű események. Az ezekbe sorolt kórfolyamatokat a következőkben részletesen tárgyaljuk. Ugyanakkor hangsúlyozzuk, hogy az összefoglalónk egy kivonat, melyben a szerzők igyekeztek bemutatni a legfontosabb információkat, de az itt feltüntetett kutatásokon és eredményeken túl további érdekes adatok érhetők el az eredeti publikációban, így összefoglalónk elolvasása nem képes kiváltani annak áttekintését.

\section{Az elsősegélynyújtás definíciója}

Az elsősegélynyújtás az első ellátás egy akut megbetegedés, vagy sérülés esetén, melynek céljai a következök: az élet megörzése, a szenvedés enyhítése, további megbetegedések megelőzése és a felépülés támogatása. Elsősegélynyújtó bárhol, bármikor, bárki lehet - beleértve a saját ellátást is. Az elsősegélynyújtás magában kell, hogy foglalja a következőket:

- felismerni, értékelni és rangsorolni az elsősegély szükségességét

- ellátás biztosítása a megfelelő kompetenciák felhasználásával, figyelembe véve a saját limitációinkat

- szükség esetén további ellátási lehetőségének biztosítása (pl. mentőhívás, egyéb orvosi/egészségügyi ellátás biztosítása)

Az elsősegélynyújtás legfőbb szabályai:

- Az elsősegélynyújtásnak orvosilag megalapozottnak kell lennie és az elérhető tudományos bizonyítékokon kell alapulnia!

- Az elsősegélynyújtás oktatásnak széles körünek kell lennie: mindenkinek kellene elsősegélyt tanulni!

- A segítségnyújtási hajlandóságot támogatni, segíteni kell: mindenki képes segíteni! 
- Az elsősegélynyújtás hatálya és a segítségnyújtói magatartás nagy variabilitást mutathat, melyet befolyásol a környezet, rendelkezésre álló erőforrások, oktatás és az aktuális szabályozások! [2]

\section{Nem traumás eredetü, sürgősségi ellátást igénylö kórképek}

\section{Stabil oldalfektetés}

Az eszméletlenség gyors beavatkozás nélkül súlyos állapotokat eredményezhet, hiszen ebben az esetben a beteg légútjának átjárhatósága veszélybe kerül. Eszméletlenséget számos tényező okozhat. Azon esetekben, amikor a beteg (akár felnőtt, akár gyermek) eszméletlen - vagy legalábbis korlátozottan vonható kontaktusba - és nem merül fel traumás eredet, mely kontraindikálná azt, a stabil oldalfekvő helyzet kialakítása javasolt. Nagyon fontos, hogy ezt csak abban az esetben végezzük, amennyiben a beteg keringése és légzése megtartott, azaz nem merül fel az újraélesztés szükségessége! Ennek oka, hogy korábbi tanulmányok kimutatták, hogy bizonyos esetben a stabil oldalfekvo" helyzet kialakítása miatt késlekedett, vagy éppen maradt el az újraélesztés megkezdése [4,5]. A stabil oldalfektetés kialakításának többféle módszere ismert, melyek hatékonyságát nehéz összehasonlítani. Az ERC a jelenlegi tudományos bizonyítékok alapján a következő módszert ajánlja $[2,3]$ :

- Térdeljünk a beteg mellé és bizonyosodjunk meg róla, hogy mindkét alsó végtagja nyújtva van!

- A hozzánk közelebbi felső végtagot derékszögben hajlítsuk be a beteg feje mellett (mintha integetne)!

- Keresztezzük a beteg mellkasát a beteg tőlünk távolabbi karjával és kezének háti részét fogjuk a hozzánk közelebbi arcfeléhez!

- A tőlünk távolabbi alsó végtagot térdben behajlítva húzzuk fel úgy, hogy közben a beteg lába a talajon marad (tehát ne emeljük meg a teljes alsó végtagot)!

- Miközben a beteg kezét továbbra is az arcánál tartjuk, a behajlított lábánál fogva fordítsuk el a beteget magunk felé!

- A felül lévő alsó végtagot igazítsuk úgy, hogy a csípő és a comb, valamint a comb és a térd is derékszöget zárjanak be egymással, ezzel is stabilizálva a beteget!

- Hajtsuk hátra a beteg fejét a légút átjárhatóságának biztosítása érdekében!
- Szükség esetén igazítsuk el úgy a beteg arca alatti kezét, hogy a fej pozícióját megtartsa, hiszen ez fontos annak érdekében, hogy az esetleges váladék (nyál, vér, hányadék) távozni tudjon a beteg száján keresztül!

- Rendszeresen ellenőrizzük a légzést!

- Csak abban az esetben hagyjuk magára a beteget a segítség megérkezéséig, ha az feltétlenül szükséges (pl. más betegek ellátása)!

A fenti mozdulatsor végrehajtása után is nagyon fontos a beteg szoros megfigyelése a szaksegítség megérkezéséig. Amennyiben időközben a beteg keringése/ légzése leáll, haladéktalanul kezdjünk újraélesztést! Azon esetekben, amikor az ellátó bizonytalan a beteg állapotában (pl. agonális légzés), vagy az esemény eredete kapcsán felmerül a trauma lehetősége, a stabil oldalfektetés nem javasolt $[2,3]$ !

\section{Az optimális testhelyzet sokkos betegek esetén}

A sokk perifériás keringési elégtelenséget jelent, melyet több ok is kiválthat (súlyos vérzés, trauma, akut miokardiális infarktus, stb.). A különböző eredetű sokkok esetében a tünetek változatos képet mutathatnak, ugyanakkor bizonyos vitális paraméterek változása nagyjából egy irányba mutat, ezért a keringés támogatása mindenképpen szükséges. A sokkos betegek esetén - legyen bármilyen eredetű a kórfolyamat - a beteg háton történő fektetése javasolt. Bizonyos esetekben találkozhatunk az alsó végtagok megemelésének technikájával is, elősegítve ezzel a vénás viszszaáramlást. Elérhető olyan tanulmány, mely az alsó végtag megemelése után átmeneti javulásról számolt be [6], ugyanakkor olyan kutatás is fellelhető, melyben további romlás történt [7]. Mivel az alsó végtag megemelésének hatékonysága kapcsán jelenleg nem rendelkezünk elég tudományos bizonyítékkal, így ez rutinszerüen nem javasolt [2,3]. Ha mégis így járunk el, előtte mindenképpen mérlegeljük a mozgatás esetleges kockázatát, a megemelés mértéke pedig 30-60 legyen.

\section{Hörgőtágító adása asztma esetén}

Az asztma hirtelen kialakulása vagy a krónikus megbetegedés akut rosszabbodása súlyos légzőszervi tünetekkel járhat. Amennyiben az asztmás beteg számára rendelkezésre áll a hörgőtágító gyógyszere („pipa”), 
az elsősegélynyújtó segítheti a gyógyszer beadását. A gyógyszer alkalmazását az elsősegélynyújtó maga is elvégezheti, ugyanakkor a hatékonyság miatt fontos, hogy a laikusoknak tanítsuk meg a különböző hörgőtágítók alkalmazásának módszereit, hiszen csak így várható valódi eredmény [2,3].

\section{Stroke észlelése}

A stroke a vezető halálokok közé tartozik világszerte [8]. Az utóbbi években számos új módszer és ellátási forma került kidolgozásra és bevezetésre, melyek nagymértékben növelték a betegségen átesettek túlélési esélyét. A szakszerű definitív ellátás mellett - és ezt megelőzően - a legnagyobb hangsúly a korai felismerésen van, hiszen ezáltal biztosítható, hogy a beteg minél kevesebb késlekedéssel kaphassa meg a számára szükséges terápiát [9]. Ennek elérése érdekében az utóbbi években számos kampány indult világszerte, melyek a stroke korai felismerésével foglalkoztak. Ennek hatására egyre inkább elterjedtek a különböző stroke-skálák, melyek már a kezdeti tünetek, panaszok kialakulásakor segíthetnek a mielőbbi felismerésben. Stroke gyanú esetén nagyon fontos, hogy - laikusként is - alkalmazzunk a különböző stroke-skálákat. Ezek széleskörü bevezetésének feltételei, hogy jól érthetők, könnyen tanulhatók és könnyen alkalmazhatók legyenek. A következő stroke-skálák alkalmazása javasolt:

- FAST (Face, Arm, Speech, Time to call - Arc, Karok, Beszéd, Mentőhívás)

- MASS (Melbourne Ambulance Stroke Scale)

- CPSS (Cincinatti Prehospital Stroke Scale)

- LAPSS (Los Angeles Prehospital Stroke Scale) (ez a leggyakoribb)

Ezek alkalmazása mind a prehospitális ellátók, mind pedig a laikusok számára javasoltak. Használatuk egyszerű, mindössze néhány jól körülhatárolt panaszt, tünetet vizsgálnak (végtagok gyengesége, bénulása, arc asszimmetriája, beszéd megváltozása, stb.), melyek könnyen felismerhetők. A MASS és a LAPSS vércukorszint méréssel is kiegészül a többi módszerhez képest, így ezek valamivel összetettebbek, ezáltal talán megbízhatóbbak is, viszont ebből következik, hogy laikusok csak abban az esetben tudják használni, ha rendelkezésre áll vércukormérő készülék és tudják is azt használni. Az ezirányú oktatás erősen javasolt annak érdekében, hogy minél jobb legyen a prognózis [2].

\section{Korai aszpirin adás mellkasi fájdalom esetén}

$\mathrm{Az}$ akut koronária szindróma (ACS) és ezen belül az akut miokardiális infarktus (AMI) esetén típusos tünetként erős mellkasi fájdalom jelentkezhet, mely a test különböző pontjaira ki is sugározhat (pl. bal kar, váll, állkapocs). Erős mellkasi fájdalom esetén fontos a beteg megnyugtatása, illetve ülő, vagy fekvő helyzetbe hozása, amely számára kényelmes. A mielőbbi segítséghívás rövidítheti a definitív ellátás megtörténtének idejét. Amennyiben nem áll fenn a traumás eredet lehetősége, illetve nincs kontraindikációja (pl. ismert emésztőrendszeri vérzés, súlyos asztma, ismeretlen eredetű mellkasi fájdalom), javasolt a betegnek 150-300 mg aszpirin rágótabletta bevétele [2]. Korábban több tanulmány is vizsgálta a korai aszpirin adást, melyek során az derült ki, hogy a gyógyszer korai adása - az esetenként esetlegesen felmerülő mellékhatások és komplikációk ellenére is - elönyös lehet [10,11].

\section{Anafilaxia}

$\mathrm{Az}$ anafilaxia egy súlyos, életet veszélyeztető kórkép, melynek ellátása a „Speciális esetek” fejezetben részletesen tárgyalásra kerül, így itt mindössze egy kiegészítéssel élnénk az adrenalin autoinjektor alkalmazása kapcsán: amennyiben a tünetek és panaszok az adrenalin beadását követő 5 percben nem enyhülnek, úgy javasolt újabb dózis intramuszkuláris adrenalin adása [2]. Annak érdekében, hogy ez valóban hatékonyan megtörténhessen, fontos a laikusok oktatása, mely során az anafilaxia gyors felismerése a cél, másrészt pedig a szükséges beavatkozás megtanítása. Korábbi vizsgálatok kimutatták, hogy a laikusok képesek voltak szimulált környezetben hatékonyan alkalmazni az autoinjektort, ugyanakkor további, valós megbetegedések során történő vizsgálatok indokoltak lennének $[12,13]$.

\section{Hipoglikémia kezelése}

Hipoglikémiáról a vércukorszint lecsökkenésekor beszélünk. A hipoglikémiának viszonylag jól körülírt tünetei vannak, melyek a laikusok számára is könnyen felismerhetők: szédülés, ájulás, idegesség, deviáns viselkedés (agresszivitás, hangulatingadozás, zavartság, koncentráció-csökkenés, részegséghez hasonló viselkedés), majd akár eszméletvesztés 
[14]. Enyhe hipoglikémia esetén a beteg képes nyelni, illetve képes követni a segítségnyújtó utasításait. Ezen esetben javasolt 15-20 g glükóz, vagy dextróz tabletta adása szájon át, vagy ezek hiányában bármilyen cukor tartalmú étel/ital (pl. gyümölcslé, cukorka, stb.). Amennyiben 15 percen belül nem javul a beteg állapota, meg kell ismételni a cukortartalmú étel/ital adását. Korábbi vizsgálatokban foglalkoztak a nyelv alól, nyálkahártyán keresztül felszívódó glükóz adagolással is, mely bár jó alternatíva lehet, ugyanakkor hatékonysága valamelyest elmarad a gyomorba jutó glükózétól [15]. Az említett glükóz gél kettős hatású is lehet, hiszen a száj nyálkahártyáján keresztül is felszívódhat, illetve lenyelve is hasznosul. Olyan esetben, amennyiben például egy gyermek a beteg, aki felszólításunkra nem nyeli le a glükóztartalmú ételt/ italt, megfontolandó egy fél teáskanál cukrot a nyelve alá tenni, hogy onnan felszívódhasson. Az esetek egy részében a megnevezett terápiára a betegek jól reagálnak, mentőhívás abban az esetben indokolt, ha a beteg eszméletlen, vagy tartósan nem javul az állapota a terápia ellenére sem. Amennyiben vércukor mérő készülék rendelkezésre áll és a segítségnyújtó tudja azt használni, mindenképpen érdemes megmérni a beteg vércukorszintjét a feltaláláskor, valamint a terápiát követően egyaránt és az értékeket dokumentálni is szükséges $[2,3]$.

\section{Szájon keresztüli rehidrációs lehetőségek a fizikai megerőltetés miatt kialakult kiszáradás esetén}

Az emberi szervezet folyadékháztartásában bekövetkező nagyobb fokú változás akár végzetes következményekkel járhat. Egy bizonyos tartományon belül bekövetkező változásokat a szervezet spontán tudja rendezni, ugyanakkor ezen tartományon kívül segítségnyújtásra van szükség. A megerőltető fizikai aktivitás (fizikai munka, sporttevékenység, stb.) - föként meleg környezetben - megfelelő odafigyelés nélkül kiszáradáshoz vezethet, mely súlyos esetben akár közvetlenül életet veszélyeztető állapottá is fokozódhat [16]. A tünetek ebben az esetben is viszonylag jól felismerhetők: szájszárazság, szomjúság, szédülés, sötét és erős szagú vizelet. Ilyen esetekben rendkívüli fontosságú a megfelelő rehidrációs terápia. A folyadékpótlásra számos lehetőség rendelkezésre áll (különböző koncentrációjú szénhidrát tartalmú italok, víz, kókusztej, juharvíz, joghurt-ital, roibos tea, kínai tea koffeinnel, lúgos víz, 3\%-os glicerin, alacsony alkoholtartalmú, vagy alkoholmentes sör, fehérje-oldat), melyek összetétele akár nagymértékben is különbözhet egymástól. A rendelkezésre álló bizonyítékok alapján érdemes különbözö koncentrációjú, szénhidrát tartalmú italok adása a betegnek, de alternatív esetben a víz is jó lehet (figyelembe véve, hogy a rehidráció ebben az esetben hosszabb időt vehet igénybe). Súlyos esetben, ha a beteg eszméletlenné válik, vagy felmerül a hőguta gyanúja, mentőt kell hívni $[2,3]$.

\section{Hőguta ellátása hűtéssel}

Hőgutáról abban az esetben beszélünk, ha a beteg testhőmérséklete meghaladja a $40{ }^{\circ} \mathrm{C}$-ot. Ilyen esetben egy súlyos, életet veszélyeztető állapotról beszélünk, mely gyors beavatkozás nélkül akár a beteg halálához is vezethet [17]. A tüneteket tekintve zavartság, magas testhőmérséklet, agitáció, eszméletlenség, görcsroham, kóma is előfordulhatnak. A kiváltó okok tekintetében beszélhetünk nem fizikai megerőltetés hatására kialakuló hőgutáról (pl. ha idősek és gyermekek - akiknek a hőregulációja rosszabb - hosszabb időt töltenek a napon), vagy kialakulhat fizikai aktivitás hatására, melyet az egyén meleg környezetben végez. A tünetek észlelésekor az első lépés, hogy a beteget minél előbb távolítsuk el a meleg környezetből. A jelenleg elérhető információk alapján a legjobb és leggyorsabb terápia hőguta esetén a teljes test (nyaktól lefele) vízbe merülése $\left(1-26^{\circ} \mathrm{C}\right)$, ugyanakkor meglepő módon közel azonos hatás volt elérhető langyos vízzel, mint jeges vízzel [3]. A vízbe merülés jóval hatékonyabbnak bizonyult, mint egyéb hűtési módszerek, mint például a jég használata hónaljban, ágyékon, nyakon, vagy a legyezés [3]. Ugyanakkor megjegyzendő, hogy a teljes test vízbe merülésének megvalósítása hiányában bármilyen hűtési technika jó lehet, a lényeg, hogy csökkenteni tudjuk a testhőmérsékletet [18]. A hütés hatékonyságának ellenőrzése érdekében szükséges a maghőmérséklet mérése (rektálisan, vagy özofageálisan, mely ugyanakkor speciális ismereteket igényel), a cél pedig a testhőmérséklet $39^{\circ} \mathrm{C}$ alá csökkentése. Ha a fent nevezett ellátási módokban a segítségnyújtó nem járatos, akkor is elengedhetetlen a gyors felismerés, segítséghívás, valamint a passzív hütés megkezdése, hiszen ezzel is csökkenthető az állapotromlás és a mortalitás [2]. 


\section{Oxigénadás akut stroke esetén}

Akut stroke fennállása esetén az oxigénadás vitatott, rutinszerű adása nem javasolt. A beteg kizárólag hipoxia fennállása esetén kapjon oxigént az elsősegélynyújtás részeként - ha az egyáltalán rendelkezésre áll. Annak érdekében, hogy a segítségnyújtó el tudja dönteni, hogy fennáll-e a hipoxia, illetve tudjon megfelelö módon oxigént adni, az elsősegélynyújtók ezirányú speciális képzésére van szükség $[2,3]$.

\section{A pre-szinkópe ellátása}

A preszinkópe az ájulást megelőző állapot, melyet számos ok kiválthat. A tünetek között szerepel a kábultság, hányinger, gyengeség, izzadás, fekete foltok megjelenése a látótérben. Ilyen esetben mindenképpen biztosítanunk kell, hogy a beteg ne essen el és ezáltal ne szerezzen különböző sérüléseket (pl. törések, koponyatrauma, stb.). Vazovagális, vagy ortosztatikus eredetű preszinkópe esetén javasolt „ellennyomást” alkalmazni az ájulás megelőzése érdekében [19]. Ez a beteg különböző végtagi izmainak összehúzásával (tehát izomerő kifejtésével), vagy éppen hasprés alkalmazásával érhető el. Ezen manőverek közül az alsó végtagiak (pl. guggolás keresztezett lábakkal, vagy anélkül, menetelés) hatékonyabbak, mint a felső végtagiak (kezek összekulcsolása, nyaki flexió) [20]. Fontos, hogy az elsősegélynyútó tisztában legyen ezen manőverek céljával és a kivitelezés megfelelő technikájával, mely érdekében speciális képzés lehet szükséges [2].

\section{Traumás eredetű események és azok ellátása}

\section{Életet veszélyeztető súlyos vérzés csillapítása}

A különböző okokból bekövetkező trauma világszerte a vezető halálokok közé tartozik. A kontrollálhatatlan vérzés a traumás esetek között a vezető halálokok közé tartozik [21]. Ilyen esetekben a gyors felismerés és beavatkozás elengedhetetlen, hiszen bizonyos esetekben a vérvesztés akár 5 percen belül a beteg halálához vezethet. Az ellátás során a legfontosabb, hogy a vérző részen direkt nyomást alkalmazzunk [2,22]. Súlyos, kontrollálhatatlan vérzés esetén, vagy olyan testtájakon, ahol a direkt nyomás önmagában nem kivitelezhető hatékonyan (pl. nyak) - annak elérhetőségekor - javasolt hemosztatikus kötszer alkalmazása (bár megemlítendő, hogy ez költségesebb megoldás), mely ugyancsak kiegészítendő direkt nyomással. Nyomókötés felhelyezése - mely hazánkban talán a legelterjedtebb módszer a köztudatban vérzéscsillapítás céljából - hatásos lehet, de önmagában nem elegendő, mindenképpen ki kell egészíteni direkt nyomással is. Hasonlóan elterjedt módszer a köztudatban az artériás nyomópontok nyomása, valamint a lokális hủtés, ezek viszont - bizonyítékok hiányában - nem javasoltak.

Bár az utóbbi években egyre többet hallani róla, hazánkban az elsősegélynyújtás részeként kevéssé ismert az úgynevezett tourniquet használata. Az eszközt súlyos, kontrollálhatatlan vérzés esetén használhatjuk, működési elvét tekintve pedig a súlyosan vérző végtag (alsó és felső egyaránt) leszorításáról van szó [23]. Az esetleges mellékhatások miatt alkalmazása csak indokolt esetekben javasolt. Amennyiben gyártói eszköz rendelkezésre áll:

- Helyezzük fel a vérző rész fölé kb. 5-7 cm-el, de semmiképpen ne ízület fölé!

- Ezt követöen húzzuk olyan szorosra, amíg a vérzés csillapodik, vagy eláll (ez nagyon fájdalmas lehet a betegnek) és tartsuk is fenn ezt a nyomást!

- Rögzítsük a felhelyezés időpontját!

- Soha ne távolítsuk el az eszközt - ezt majd az egészségügyi szakemberek fogják megtenni!

- Biztosítsuk, hogy a sérült mielőbb kórházba kerülhessen!

- Extrém esetben akár két tourniquet párhuzamos alkalmazása is szóba jöhet.

Amennyiben tourniquet nem áll rendelkezésre, alkalmazzuk a feljebb megnevezett ellátást (direkt nyomás a vérző részre kesztyűs kézzel, hemosztatikus kötszer). Amennyiben az elsősegélynyújtónak van ezirányú képzettsége - és a direkt nyomás nem hatékony, valamint gyártói tourniquet nem áll rendelkezésre - megfontolandó valamilyen alkalmi eszköz e célból történő használata (pl. kendő, egyéb ruhadarab). Megjegyzendő, hogy utóbbi megoldások kevésbé hatékonyak, mint a gyártói tourniquet alkalmazása. Kis méretű végtag, illetve csecsemők, kisgyermekek esetén nem érhető el a kívánt hatás, így ilyenkor direkt nyomás és hemosztatikus kötszer alkalmazása javasolt [2,3]. 


\section{Nyílt mellkasi sérülés ellátása}

A nyílt mellkasi sérülés nagyon veszélyes állapot lehet a sérültre nézve. Nyílt mellkasi sérülés esetén az ellátás során nagyon fontos, hogy hagyjuk a sérült részt szabadon, nem szükséges kötéssel fednünk, körbetekernünk, hogy a szellözés biztosított legyen, máskülönben nagy az esélye a tenziós PTX kialakulásának [24]. Amennyiben lokális vérzést látunk, azt próbáljuk direkt nyomással csillapítani. Ha mégis fedést alkalmazunk, az mindenképpen biztosítsa a megfelelő szellőzést. Utóbbit viszont csak képzett segítségnyújtók alkalmazzák $[2,3]$ !

\section{A nyaki gerinc mozgásának korlátozása és annak stabilizálása, gerincvédelem}

A nyaki gerinc sérülése nem gyakori esemény, ugyanakkor bekövetkezte esetén súlyos szövődmények léphetnek fel [25]. A nyaki gerinc rögzítésére rendelkezésre állnak eszközös és eszköz nélküli megoldások. Nyakrögzítő gallér rutinszerű alkalmazása elsősegélynyújtók számára nem javasolt, illetve általában nem is elérhető laikusok számára, így a manuális stabilizáló módszerek alkalmazása nyújthat segítséget. Amennyiben a sérült kontaktusképes és tudja követni az utasításokat, kérjük meg, hogy saját maga tartsa a fejét és nyaki gerincét stabil pozícióban, ne mozogjon. Amennyiben a sérült eszméletlen, úgy a nyaki gerinc védelmét az ellátónak kell biztosítania. Ezt megteheti a következő módszerekkel, miközben a beteg a hátán fekszik:

- Fogjuk meg a beteg fejét úgy, hogy hüvelykujjaink a sérült fülei felett, míg többi ujjunk azok alatt helyezkedjenek el (semmiképpen ne fogjuk be a fülét, megfosztva ezzel a hallástól)!

- Kezeinkkel fogjuk meg a trapézizmát (hüvelykujj felül, többi ujj alul), illetve alkarunkkal támasszuk meg a beteg fejét, nagyjából a fülek vonalában $[2,3]$.

\section{Agyrázkódás felismerése}

A kisebb fej-koponyatraumák gyakran előfordulnak akár gyermekek, akár felnőttek esetében. Az agyrázkódás időben történő felismerése kulcsfontosságú, mert a későbbiekben ellátás nélkül súlyos következményekkel, akár a beteg halálával is járhat. Vannak viszonylag jól felismerhetö tünetek (fejfájás, szédülés, stb.), de ezek felismerése - oktatás nélkül - nem mindig elvárható egy laikustól. Tovább nehezíti a helyzetet, hogy a tünetek bizonyos esetekben rögtön a behatás után jelentkeznek, máskor viszont csak később. Bár rendelkezésre állnak olyan score rendszerek, melyek segítségével viszonylag jól felismerhető a kórfolyamat, viszont ezek széles körü elterjedése laikus ellátók körében még nem megszokott (több esetben nem is találtak olyan validált eszközt, amely minden tekintetben alkalmas erre a célra [3]). Az agyrázkódás diagnózisának felállítása esetén javasolt, hogy ilyen esetben a vizsgálatot egészségügyi szakember végezze el.

Néhány használt score-rendszer az agyrázkódás felismerésére [2]:

- Sport Concussion Assessment Tool (SCAT 5): különböző sporteseményeken viszonylag széles körben alkalmazott. Bevezetése óta több adat is azt mutatja, hogy gyorsabb lett az agyrázkódás felismerése és a kezelés megkezdése. Ugyanakkor hátránya, hogy más környezetben nem alkalmazható megfelelően [26].

- Concussion Recignition Tool (CRT 5): 2017ben került bevezetésre laikusok körében, de egyelöre nem állnak rendelkezésre tudományos bizonyítékok alkalmazásával kapcsolatban [27].

- Glasgow Coma Scale (GCS): a prehospitális- és hospitális sürgősségi ellátók körében széles körben alkalmazott, de laikusok számára az alkalmazása kevésbé javasolt. Az eszméletlenség mélységét vizsgálja három fö tényező alapján (szemnyitás, motoros válasz, verbális válasz), melyek végül egy számértéket adnak ki, melyből lehet következtetni a beteg állapotára [28].

- AVPU-skála: hasonlóan az előzőhöz, ez is inkább szakemberek által használt módszer, illetve megemlítendő, hogy az eszméletlenség fokáról ad visszajelzést, önmagában nem képes az agyrázkódás megállapítására. A sérülteket né kategóriába sorolja: $\mathrm{A}=$ éber, $\mathrm{V}=$ hangingerre reagál, $\mathrm{P}=$ fájdalomingerre reagál, $\mathrm{U}=$ nem reagál. Amennyiben a beteg nem „A” értékelést kap, mindenképpen szükséges további egészségügyi vizsgálat.

- 2-stage concussion scoring scales: ennek több formája is ismert, viszont egyik sem javasolt laikus segítségnyújtók számára [29].

\section{Égési sérülések}

Égési sérülés esetén az elsődleges ellátás a hideg (de nem fagyos), folyó vízzel történő azonnali hủtés, legalább 20 
percig. Ennek jótékony hatásai több területen is megfigyelhetők: csökkentheti az égés mélységét, fájdalomcsillapító hatású, csökkenti az ödémaképződés esélyét, csökkenti a fertőzés esélyét, illetve gyorsíthatja a gyógyulás folyamatát [30]. A hűtés során - kiváltképpen nagy felületű égési sérülés esetén, csecsemők és kisgyermekek esetén - ügyeljünk arra, hogy ne okozzunk hipotermiát! Ezt követően a sebet fedjük laza, steril fedőkötéssel, illetve szükség esetén hívjunk segítséget $[2,3]$.

\section{Fogászati esemény}

A kitört maradandó fog az egyik legsürgetőbb fogászati kórkép, mely gyors felismerést és beavatkozást igényel [31]. Mint a legtöbb esetben, itt is az első észlelők általában laikus személyek (szülők, tanárok), akik a megfelelő ismeretek hiányában sajnos legtöbbször késve cselekednek, pedig a visszaültethetőség szempontjából a minél előbbi segítségnyújtás elengedhetetlen [32,33]. Kiesett/ kitört fog esetén a segítségnyújtó mindenképpen viseljen kesztyűt, mielőtt megkezdi az ellátást. Öblítsük ki a sérült száját tiszta, hideg vízzel. Amennyiben az eltávolított fog környezete vérzik, nedves borogatással próbáljunk direkt nyomást kifejteni úgy, hogy a beteget megkérjük, hogy ráharapjon. Ügyeljünk rá, hogy ez a módszer veszélyes lehet olyan személyeknél, akiknél fennáll a lehetősége, hogy lenyelik a borogatást (pl. kisgyermekek, agitált személyek), így ilyen esetben ezt ne alkalmazzuk $[2,3]$ !

A fog kitörése esetén a kitört fog mielőbbi visszaültetése nagyon fontos, de ez a legtöbb esetben nem oldható meg azonnal. Ilyenkor biztosítanunk kell a fog „túlélését”, biztonságos szállítását. Ehhez ügyeljünk arra, hogy csak a kellő mértékben és ideig fogjuk meg a fogat (akkor is a koronánál, ne nyúljunk a gyökérhez). Maximum 10 másodpercig tisztíthatjuk csapvízzel, utána pedig a szállításhoz csomagoljuk fóliába, vagy speciálisan erre a célra gyártott tárolóba. Alternatívaként tehéntejben történő tárolás is megfelelő lehet, hangsúlyozva, hogy semmiképpen ne más tejtermékben, csapvízben, vagy sóoldatban történjen a tárolás [2,3]!

\section{Kompressziós kötés zárt ízületi sérülések esetén}

A különböző végtagi ízületi sérülések esetén a diagnózis megalkotását segíthetik a fennálló panaszok és tünetek: fájdalom, véraláfutás, duzzanat, funkciókiesés.
Az egyik leggyakoribb ezen sérülések között a boka rándulása, mely sportolók, illetve fizikai munkát végző személyek között fordul elő fóként [34]. Ha a sérült számára fájdalmas a mozgatás, kérjük meg, hogy maradjon nyugalomban. A jelenleg alkalmazott, akronímmal jelölt módszerek (pl. RICE, PRICE, PEACE and LOVE) mindegyike kompressziós kötést/ rögzítést javasol $[35,36]$. A rögzítő kötés felhelyezésének hatékonysága kapcsán jelenleg nem állnak rendelkezésre tudományos bizonyítékok annak tekintetében, hogy a rögzítés kompressziós, vagy anélküli legyen, így a jelenlegi ajánlás mindkettőt megengedi. Fontos, hogy csak olyan segítségnyújtó helyezzen fel kötést rögzítés gyanánt, aki ebben járatos [2].

\section{Törések kiegyenesítése}

Törések, rándulások és ficamok viszonylag gyakran előfordulnak. Bizonyos esetekben - megfelelő ellátás nélkül - súlyos következményekkel járhatnak. Ilyen lehet például a végtag keringésének romlása. Törött végtagok esetén a végtag kiegyenesítése nem javasolt, a végtagot a talált helyzetben kell rögzítenünk. Az ellátás során gyakori módszer a sínezés, mellyel védhetjük a végtagot a további sérülésektől. Ennek alkalmazásakor figyelnünk kell, hogy a rögzítésben a sérüléshez képest a két szomszédos ízület részét képezze a rögzítésnek. A törések repozícióját kizárólag ebben járatos egészségügyi szakember végezheti, laikusok számára egyáltalán nem ajánlott $[2,3]$.

\section{Kémiai behatás általi szemsérülés}

Kémiai anyagok okozta szemsérülés főként a háztartásokban, illetve kémiai anyagokkal dolgozó személyek esetén fordul elő. Ilyen esetben fontos az érintett szem (és csak annak) azonnali dekontaminációja folyó vízzel, vagy fiziológiás sóoldattal 10-20 perce keresztül. Ezt követően mindenképpen szükséges, hogy szakember is megvizsgálja a sérültet, így ezt biztosítsuk számára. A saját védelmünk érdekében - mivel nem mindig ismert a kémiai anyag - minden esetben viseljünk kesztyüt, amit a használat után úgy kezeljünk, hogy más se érintkezhessen vele. A savas (fehérje koaguláció) és lúgos (súlyos cornea sérülés, akár vakság) hatású anyagok esetén más-más tünetek és hatásmechanizmus figyelhetők meg, de az azonnali beavatkozás bármely esetben fontos [2, 37]. 


\section{Kulcs-üzenetek}

Hasonlóan az ERC 2021-es ajánlásának többi fejezetéhez, az elsősegélynyújtás kapcsán is megfogalmazásra került az 5 fö üzenet. Összefoglalónkat ezek ismertetésével - egyfajta „take-home-message”-ként - zárjuk:

1. Csak olyan esetben alkalmazzunk stabil oldalfektetést, amikor nem jön szóba az újraélesztés szükségessége (tehát a betegnek van kielégítő légzése)!

2. A stroke mielőbbi felismerése érdekében alkalmazzunk különböző stroke-skálákat!

3. Hőguta esetén (akár fizikai aktivitásból származó megerőltetésre alakult ki, akár attól függetlenül) azonnal vigyük el a beteget a meleg környezetből és kezdjünk passzív hűtést, illetve bizonyos esetekben alkalmazzunk alternatív hütési megoldásokat!

4. Súlyos külső vérzés esetén azonnal alkalmazzunk direkt nyomást a vérző részen, valamint mérlegeljük a nyomókötés, illetve a tourniquet szükségességét!

5. Égési sérülés esetén azonnal távolítsuk el a sérültet a hőforrástól, majd rögtön hütsük a sérülést hideg, folyó vízzel, legalább 20 percig! Ezt követően helyezzünk fel steril fedőkötést!

Ahogy látható a jelenlegi ajánlásból is, az elsősegélynyújtás köre egyre szélesebbé válik, a „hagyományosan” ebbe a tárgykörbe tartozó kórfolyamatok és ellátásuk mellett további új teendők jelentek meg, melyek ugyancsak a laikusok kompetencikörébe tartoznak, ezáltal növelve a bajbajutottak túlélési esélyét [2].

\section{Szerzői végszó}

Az összefoglalót készítő szerzőkként a fentieket összefoglalva, illetve bizonyos tekintetben kiegészítve szeretnénk néhány kulcspontot megadni, amelyeket mindenképpen szükségesnek tartunk figyelembe venni, amikor elsősegélynyújtásról beszélünk:

- Ahogy látható is az ERC irányelvéből, már nemcsak a laikusok körében szélesebb körben elterjedt „hagyományos” elsősegélynyújtásról beszélünk, hanem ez is egy olyan tudományterület, amely a betegek/sérültek érdekében folyamatosan bővül - és ez így van jól. Látható, hogy nemcsak a különböző manőverek köre javasolt egyre szélesebb körben, hanem több esetben felmerül akár a gyógyszeradás lehetősége - természetesen megfelelő képzést követően, a szükséges körültekintéssel.

- Ahogy több esetben is említésre került, a legtöbb területen egyelöre nagyon limitált arányban érhetők el tudományos bizonyítékok, így további kutatások elvégzése elengedhetetlen, mely egyaránt lehet képes segíteni a bajbajutottat és az ellátót is.

- Nagyon fontos hangsúlyozni, hogy az elérhető irányelvek egy „nagy átlagot” mutatnak be, nem lehet mindent minden körülmények között alkalmazni (pl. azon vizsgálatok, beavatkozások, melyeknek tárgyi erőforrás igénye van). Éppen ezért a hatályos irányelvek implementálása során mindig figyelembe kell venni a helyi viszonyokat, lehetőségeket és korlátokat, majd ezek mérlegelésével eljárni.

- Bár még mindig gyakran él a laikusok körében az „ártani nem akarás” pszichológiája, de ahogy látható az összefoglalóból is, elmondhatjuk, hogy szinte minden jobb és jobban szolgálja a bajbajutott érdekeit, mint nem tenni semmit! Ez persze nem jelenti azt, hogy nem tudunk ártani a betegnek, ezért természetesen szükséges az odafigyelés és a gyakorlat! Utóbbi figyelembe vételével mi is hangsúlyozni szeretnénk a rendszeres és magas minőségű oktatás jelentőségét, mely képes felkészíteni a laikusokat az esetleges beavatkozást igénylö - akár speciális - helyzetekre!

- A bemutatott irányelv nem tartalmazza azokat a speciális szempontokat, melyek figyelembe vétele a jelenleg zajló COVID-19 pandémia során elengedhetetlen, így a járványhelyzet fennállása ideje alatt mindenképpen javasoljuk ezek áttekintését is $[38,39]$ !

\section{Anyagi támogatás}

Az Innovációs és Technológiai Minisztérium ÚNKP20-4-II kódszámú Új Nemzeti Kiválóság Programjának a Nemzeti Kutatási, Fejlesztési és Innovációs Alapból finanszírozott szakmai támogatásával készült.

Az Innovációs és Technológiai Minisztérium ÚNKP20-3-II kódszámú Új Nemzeti Kiválóság Programjának a Nemzeti Kutatási, Fejlesztési és Innovációs Alapból finanszírozott szakmai támogatásával készült. 


\section{Irodalomjegyzék}

1. Zideman DA, De Buck EDJ, Singletary EM, et al. European Resuscitation Council Guidelines for Resuscitation 2015 Section 9. First aid. Resuscitation 2015;95:278-87.

2. Zideman DA, Singletary EM, Borra V, et al. European Resuscitation Council Guidelines 2021: First aid. Resuscitation 2021; 161: 270-290.

3. on behalf of the First Aid Science Collaborators. Singletary EM, Zideman DA, Bendall JC, et al. 2020 International Consensus on First Aid Science With Treatment Recommendations. Resuscitation 2020, doi:http:// dx.doi.org/10.1016/j.resuscitation.2020.09.016.

4. Freire-Tellado M, Navarro-Patón R, del Pavón-Prieto MP, Fernández-López M, Mateos-Lorenzo J, LópezFórneas I. Does lying in the recovery position increase the likelihood of not delivering cardiopulmonary resuscitation? Resuscitation 2017;115:173-7.

5. Navarro-Patón R, Freire-Tellado M, FernándezGonzález N, Basanta-Camiño S, Mateos-Lorenzo J, Lago-Ballesteros J. What is the best position to place and re-evaluate an unconscious but normally breathing victim? A randomised controlled human simulation trial on children. Resuscitation 2019;134:104-9.

6. Jabot J, Teboul JK, Richard C, Monnet X. Passive leg raising for predicting fluid responsiveness: importance of postural change. Intensive Care Med 2009;35:8990.

26. Gaffney FA, Bastian BC, Thal ER, Atkins JM, Blomqvist CG. Passive leg raising does not produce a significant or sustained autotransfusion effect. J Trauma 1982;22:190-3.

7. Toppen W, Aquije Montoya E, Ong S, et al. Passive leg raise: feasibility and safety of the maneuver in patients with undifferentiated shock. J Intensive Care Med 2020;35:1123-8.

8. Mortality GBD. Causes of Death C, Global, regional, and national life expectancy, all-cause mortality, and cause-specific mortality for 249 causes of death, 19802015: a systematic analysis for the Global Burden of Disease Study 2015. Lancet 2016;388:1459-544.

9. Lin CB, Peterson ED, Smith EE, et al. Emergency medical service hospital prenotification is associated with improved evaluation and treatment of acute ischemic stroke. Circ Cardiovasc Qual Outcomes 2012;5:514-22.

10. ISIS-2 (Second International Study of Infarct Survival) Collaborative Group. Randomised trial of intravenous streptokinase oral aspirin both, or neither among 17,187 cases of suspected acute myocardial infarction. Lancet 1988;2:349-60.

11. Simonsson M, Wallentin L, Alfredsson J, et al. Temporal trends in bleeding events in acute myocardial infarction: insights from the SWEDEHEART registry. Eur Heart J 2020;41:833-43.

12. Brockow K, Schallmayer S, Beyer K, et al. Effects of a structured educational intervention on knowledge and emergency management in patients at risk for anaphylaxis. Allergy 2015;70:227-35.

13. Litarowsky JA, Murphy SO, Canham DL. Evaluation of an anaphylaxis training program for unlicensed assistive personnel. J School Nurs. 2004;20:279-84.

14. Ostenson CG, Geelhoed-Duijvestijn P, Lahtela J, et al. Self-reported non-severe hypoglycaemic events in Europe. Diabet Med 2014;31:92-101.

15. DeBuckE, Borra V, Carlson JN,Zideman DA, Singletary EM, Djärv T. First aid glucose administration routes for symptomatic hypoglycaemia. Cochrane Database Syst Rev 2019, doi: http://dx. doi.org/10.1002/14651858. CD013283.pub2 Art. No.: CD013283.

16. Carter R, Cheuvront SN, Vernieuw CR, Sawka MN. Hypohydration and prior heat stress 360 exacerbates decreases in cerebral blood flow velocity during standing. J Appl Physiol 2006;101:1744-50.

17. Bouchama A, Knochel JP. Heat stroke. N Engl J Med 2002;346:1978-88.

18. Douma MJ, Aves T, Allan KS, et al. First aid cooling techniques for heat stroke and exertional hyperthermia: a systematic review and meta-analysis. Resuscitation 2020;148:173-90.

19. PC-Trial Investigators. van Dijk N, Quartieri F, Blanc $\mathrm{J}-\mathrm{J}$, et al. Effectiveness of physical counterpressure maneuvers in preventing vasovagal syncope. J Am Coll Cardiol 2006; 48:1652-7.

20. Jensen JL, Ohshimo S, Cassan P, et al. Immediate interventions for presyncope of vasovagal or orthostatic origin: a systematic review.

Prehosp Emerg Care 2020;24:64-76.

21. Kauvar DS, Lefering R, Wade CE. Impact of hemorrhage on trauma outcome: an overview of epidemiology, clinical presentations, and therapeutic considerations. J Trauma 2006;60:S3S11.

22. Charlton NP, Swain JM, Brozek JL, et al. Control of severe, lifethreatening external bleeding in the 
out-of-hospital setting: a systematic review. Prehosp Emerg Care 2020;27:1-33.

23. Teixeira PGR, Brown CVR, Emigh B, et al. Civilian prehospital tourniquet use is associated with improved survival in patients with peripheral vascular injury. J Am Coll Surg 2018226:769-776e1.

24. Ayling J. An open question. Emerg Med Serv 2004;33:44.

25. Oliver $M$, Inaba $K$, Tang A, et al. The changing epidemiology of spinal trauma: a 13 year review from a Level I trauma centre. Injury 2012;43:1296-300.

26. Echemendia RJ, Meeuwisse W, McCrory P, et al. The Sport Concussion Assessment Tool 5th Edition (SCAT5): background and rationale. Br J Sports Med. 2017;51:848-50.

27. Concussion recognition tool 5. Br J Sports Med. 2017;51:872.

28. Teasdale G, Jennett B. Assessment of coma and impaired consciousness: a practical scale. Lancet 1974;304:81-4.

29. Pabian PS, Oliveira L, Tucker J, Beato M, Gual C. Interprofessional management of concussion in sport. Phys Ther Sport 2016;23:123-32.

30. Nguyen NL, Gun RT, Sparnon AL, Ryan P. The importance of immediate cooling a case series of childhood burns in Vietnam. Burns 2002;28:173-6.

31. Lam R. Epidemiology and outcomes of traumatic dental injuries: a review of the literature. Aust Dent J. 2016;61:4-20.
32. Ozer S, Yilmaz Ei Fau-Bayrak S, Bayrak S, Fau-Tunc ES, Tunc ES. Parental knowledge and attitudes regarding the emergency treatment of avulsed permanent teeth. Eur J Dent 2012;6:370-5.

33. Marcano-Caldera M, Mejia-Cardona JL, Parra Sanchez $\mathrm{JH}$, et al. Knowledge about emergency dental trauma management among school teachers in Colombia: a baseline study to develop an education strategy. Dent Traumatol. 2018;34:164-74.

34. Fong DT, Hong Y, Chan LK, Yung PS, Chan KM. A systematic review on ankle injury and ankle sprain in sports. Sports Med 2007;37:73-94.

35. Bleakley CM, Glasgow P, MacAuley DC. PRICE needs updating, should we call the POLICE? Br J Sports Med 2012;46:220-1.

36. Dubois B, Esculier JF. Soft-tissue injuries simply need PEACE and LOVE. Br J Sports Med 2020;54:72-3.

37. Pargament JM, Armenia J, Nerad JA. Physical and chemical injuries to eyes and eyelids. Clin Dermatol. 2015;33:234-7.

38. Nolan JP, Monsieurs KG, Bossaert L, et al. European Resuscitation Council COVID-19 guidelines executive summary. Resuscitation 2020; 153: 45-55.

39. Betlehem J, Bánfai-Csonka H, Musch J, Deutsch K, Sánta E, Bánfai B. Az elsősegélynyújtási attitűd változása a COVID-19-járvány idején. Orv Hetil 2021;162:571-578. 